\title{
Luminescence dating of eolian and fluvial archives in the middle and lower Danube catchment and the paleoenvironmental implications
}

\author{
Janina Johanna Bösken \\ Chair of Physical Geography and Geoecology, Department of Geography, \\ RWTH Aachen University, 52062 Aachen, Germany
}

Correspondence: Janina Johanna Bösken (janina.boesken@geo.rwth-aachen.de)

Relevant dates: $\quad$ Received: 23 March 2020 - Revised: 2 June 2020 - Accepted: 2 July 2020 Published: 3 August 2020

How to cite: Bösken, J. J.: Luminescence dating of eolian and fluvial archives in the middle and lower Danube catchment and the paleoenvironmental implications, E\&G Quaternary Sci. J., 69, 89-92, https://doi.org/10.5194/egqsj-69-89-2020, 2020.

Supervisor: Frank Lehmkuhl

Co-Supervisor: Helmut Brückner

Dissertation online:

https://doi.org/10.18154/RWTH-2018-01253

The presented doctoral dissertation uses luminescence dating techniques to reconstruct the paleoenvironmental and paleoclimatic conditions in the middle and lower Danube catchments, especially during the period of anatomically modern humans' emergence in Europe. The thesis is embedded in the CRC806 "Our Way to Europe" project. To increase one's understanding of the environmental and climatic conditions during the last $150 \mathrm{ka}$, four loess-paleosol sequences (LPS) and one fluvial section were investigated (Fig. 1). The research area is located at the junction of Atlantic, Mediterranean and continental climatic regimes, which makes it sensitive to climatic changes. Moreover, the geographical position between Asia, Near East and Central Europe and the vast river network connecting these regions make the area a favorable pathway for anatomically modern human migration. The sediments of the five investigated sites cover various time frames from the penultimate interglacial to the Holocene. The methodological approach focused on optically stimulated luminescence dating, but for some of the sections the geochronological methods were combined with physical, biological and geochemical proxy data to reconstruct the paleoenvironmental conditions.

In the middle Danube basin three sites were investigated. The Ságvár LPS is located in the central basin and its sediments accumulated during the last glacial maximum (LGM) from approximately $25-17 \mathrm{ka}$ (Bösken et al., 2018). The sequence can be correlated to two Gravettian occupation layers. Paleoenvironmental conditions changed rapidly and Gravettian occupation took place during a typically cold LGM phase. This shows that environmental conditions were not uniform during MIS 2 and that paleoenvironmental changes can be observed even on short (millennial) timescales within rather pure loess formation.

The Bodrogkeresztúr LPS is located in the foothills of the Carpathians in the northern edge of the basin. Its sediments accumulated between $33.5 \pm 2.5$ and $28.0 \pm 2.1 \mathrm{ka}$, and the site is characterized by a well-developed MIS 3 paleosol indicating humid paleoclimatic conditions (Bösken et al., 2019). Also during loess deposition, relatively mild paleoclimatic conditions prevailed. Measurements of the anisotropy of the magnetic susceptibility revealed that the loess likely originated from the Tisza floodplain from a northeastern wind direction. The findings highlight the unique microclimatic con- 


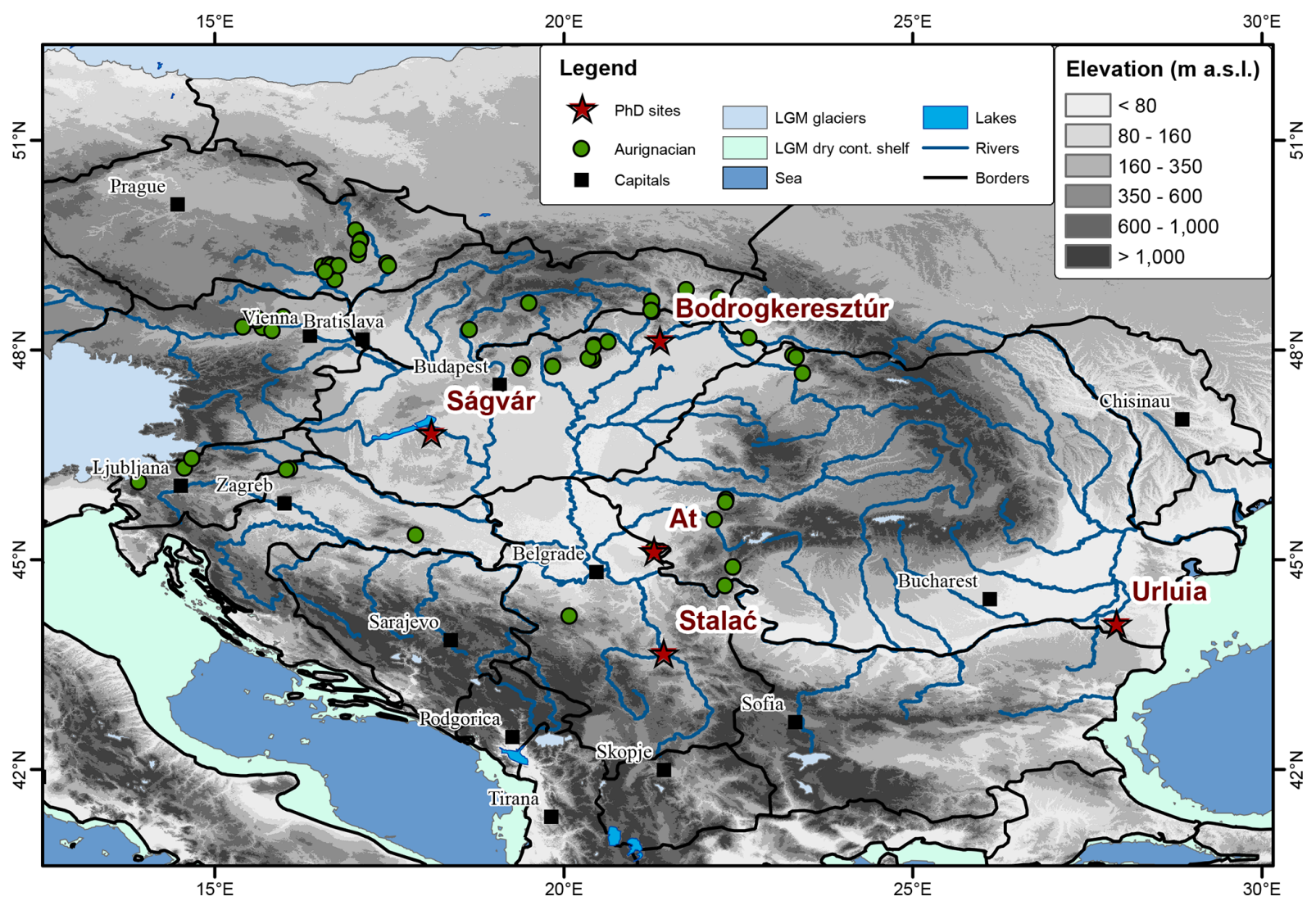

Figure 1. The map shows the location of the investigated sections, Aurignacian findspots (only middle Danube basin; Hauck et al., 2017), the LGM glacial extent (Ehlers et al., 2011) and dry continental shelf (Willmes, 2015), and the elevation (credit: AW3D30, JAXA).

ditions at the foothills of the Carpathians, which may have offered a favorable environment for Upper Paleolithic populations.

The Crvenka-At site contains fluvial sediments and Aurignacian artifacts that were found in sediments with an age between $41.3 \pm 3.6$ and $33.9 \pm 2.9 \mathrm{ka}$. This age range fits well with other dated Aurignacian findings in the Banat region, points to a more widespread occurrence of anatomically modern humans than previously thought and shows that also lowland areas were attractive for occupation.

Further south, the Stalać section is located in the interior of the Central Balkan region, in a zone of paleoclimatic shifts between continental and Mediterranean climate regimes. A firm chronology framing the last two glacial cycles was established (Bösken et al., 2017a). The lowermost paleosol (MIS 7) was characterized by stronger weathering indicating more humid and warmer paleoenvironmental conditions. The paleoclimate likely changed from a Mediterranean influence to more continental conditions with a trend of decreasing precipitation. During MIS 5 and MIS 3 similar climatic conditions prevailed, which is shown by the formation of three Kastanozems. Further paleoenvironmental analysis was conducted in Obreht et al. (2016).
Finally, the Urluia LPS in the lower Danube basin was investigated. The section was dated from $144.9 \pm 12.2$ to $21.0 \pm 1.6 \mathrm{ka}$. While the chronology of the upper $7 \mathrm{~m}$ of the section is supported by independent age control in form of the Campanian Ignimbrite/Y-5 tephra, the lower part of the sequence remains less well constrained. A rapid increase in ages between $\sim 7$ and $9 \mathrm{~m}$ is followed by rather constant ages $>130 \mathrm{ka}$ in the lower $7 \mathrm{~m}$ of the profile. These ages are in contrast with the correlation of a well-developed paleosol at the bottom of the section to MIS 5. Several hypothesis trying to explain these findings were explored but could not be solved satisfactorily. A first paleoenvironmental study is presented by Obreht et al. (2017).

The doctoral dissertation demonstrates that a detailed investigation is necessary in order to build robust age models. Luminescence signal (fading) and saturation characteristics need to be examined next to the usual applied tests, especially for minerals with high doses. The investigations at Urluia and Stalać demonstrated that, while it is possible to date polymineral samples with higher doses than quartz samples, it remains unclear up to which dose range age estimates are reliable. Another important aspect is the discrepancy between measured values of $\alpha$ efficiency ( $a$ value) and used literature values. A new $a$ value for pIRIR 290 protocols was 
suggested in another publication that includes data measured for this dissertation (Schmidt et al., 2018).

Overall, this doctoral dissertation highlights the importance of luminescence dating in paleoenvironmental and geoarchaeological studies. It demonstrates how the combination of multiple proxy data enhances the paleoenvironmental interpretations and identifies remaining challenges. The paleoclimatic dynamics in the research area at the junction of Atlantic, Mediterranean and continental climatic regimes are discussed. Finally, paleoenvironmental conditions during phases of Upper Paleolithic occupation were equally diverse, highlighting anatomically modern humans' ability to adapt to changing paleoenvironments.

Data availability. The research data of this dissertation are available within the appendix and the supplementary materials of Bösken et al. (2017a, 2018, 2019). Further data from the Ságvár LPS can be accessed at https://doi.org/10.1594/PANGAEA.868360 (Bösken et al., 2016a), https://doi.org/10.1594/PANGAEA.868361 (Bösken et al., 2016b), https://doi.org/10.1594/PANGAEA.868362 (Bösken et al., 2016c), https://doi.org/10.1594/PANGAEA.868363 (Bösken et al., 2016d), https://doi.org/10.1594/PANGAEA.868364 (Bösken et al., 2016e), https://doi.org/10.1594/PANGAEA.868365 (Bösken et al., 2016f), https://doi.org/10.1594/PANGAEA.868368 (Bösken et al., 2016g), https://doi.org/10.1594/PANGAEA.879801 (Bösken et al., 2017b), and https://doi.org/10.1594/PANGAEA.879802 (Bösken et al., 2017c).

Competing interests. The author declares that there is no conflict of interest.

Acknowledgements. The dissertation was carried out in the CRC806 "Our way to Europe" project, funded by the German Research Foundation (DFG, grant no. 57444011).

Financial support. This research has been supported by the DFG (SFB 806, grant no. 57444011).

The article processing charge was funded by the Quaternary scientific community, as represented by the host institution of EGQSJ, the German Quaternary Association (DEUQUA).

Review statement. This paper was edited by Christopher Lüthgens and reviewed by one anonymous referee.

\section{References}

Bösken, J., Zeeden, C., Hambach, U., Obreht, I., and Lehmkuhl, F.: Color characteristics of profile S1 from site "Ságvár Lyukas Hill" (Hungary), PANGAEA, https://doi.org/10.1594/PANGAEA.868360, 2016a.
Bösken, J., Zeeden, C., Hambach, U., Obreht, I., and Lehmkuhl, F.: Color characteristics of profile S2 from site "Ságvár Lyukas Hill" (Hungary), PANGAEA, https://doi.org/10.1594/PANGAEA.868361, 2016 b.

Bösken, J., Zeeden, C., Hambach, U., Obreht, I., and Lehmkuhl, F.: Geochemistry of profile S1 from site "Ságvár Lyukas Hill" (Hungary), PANGAEA, https://doi.org/10.1594/PANGAEA.868362, 2016c.

Bösken, J., Zeeden, C., Hambach, U., Obreht, I., and Lehmkuhl, F.: Geochemistry of profile S2 from site "Ságvár Lyukas Hill" (Hungary), PANGAEA, https://doi.org/10.1594/PANGAEA.868363, 2016d.

Bösken, J., Zeeden, C., Hambach, U., Obreht, I., and Lehmkuhl, F.: Granulometry of profile S1 from site "Ságvár Lyukas Hill" (Hungary), PANGAEA, https://doi.org/10.1594/PANGAEA.868364, 2016e.

Bösken, J., Zeeden, C., Hambach, U., Obreht, I., and Lehmkuhl, F.: Granulometry of profile S2 from site "Ságvár Lyukas Hill” (Hungary), PANGAEA, https://doi.org/10.1594/PANGAEA.868365, $2016 f$.

Bösken, J., Zeeden, C., Hambach, U., Obreht, I., and Lehmkuhl, F.: Profile characteristics of the last glacial Gravettian site "Ságvár Lyukas Hill" (Hungary), PANGAEA, https://doi.org/10.1594/PANGAEA.868368, 2016g.

Bösken, J., Klasen, N., Zeeden, C., Obreht, I., Marković, S. B., Hambach, U., and Lehmkuhl, F.: New luminescence-based geochronology framing the last two glacial cycles at the southern limit of European Pleistocene loess in Stalać (Serbia), Geochronometria, 44, 150-161, doi:10.1515/geochr-2015-0062, 2017a.

Bösken, J., Zeeden, C., Hambach, U., Obreht, I., and Lehmkuhl, F.: Magnetic susceptibility of profile S1 from site "Ságvár Lyukas Hill” (Hungary), PANGAEA, https://doi.org/10.1594/PANGAEA.879801, $2017 \mathrm{~b}$.

Bösken, J., Zeeden, C., Hambach, U., Obreht, I., and Lehmkuhl, F.: Magnetic susceptibility of profile S2 from site "Ságvár Lyukas Hill" (Hungary), PANGAEA, https://doi.org/10.1594/PANGAEA.879802, 2017c.

Bösken, J., Sümegi, P., Zeeden, C., Klasen, N., Gulyás, S., and Lehmkuhl, F.: Investigating the last glacial Gravettian site "Ságvár Lyukas Hill" (Hungary) and its paleoenvironmental and geochronological context using a multi-proxy approach, Palaeogeogr. Palaeocl., 509, 77-90, doi:10.1016/j.palaeo.2017.08.010, 2018.

Bösken, J., Obreht, I., Zeeden, C., Klasen, N., Hambach, U., Sümegi, P., and Lehmkuhl, F.: High-resolution paleoclimatic proxy data from the MIS3/2 transition recorded in northeastern Hungarian loess, Quatern. Int., 502, 95-107, doi:10.1016/j.quaint.2017.12.008, 2019.

Ehlers, J., Gibbard, P. L., and Hughes, P. D.: Quaternary Glaciations - Extent and Chronology, 1st Edition, Elsevier, Amsterdam, the Netherlands, Oxford, UK, 2011.

Hauck, T. C., Lehmkuhl, F., Zeeden, C., Bösken, J., Thiemann, A., and Richter, J.: The Aurignacian way of life: Contextualizing early modern human adaptation in the Carpathian Basin, Quatern. Int., 485, 150-166, doi:10.1016/j.quaint.2017.10.020, 2017.

Obreht, I., Zeeden, C., Hambach, U., Veres, D., Marković, S. B., Bösken, J., Svirčev, Z., Bačević, N., Gavrilov, M. B., and 
Lehmkuhl, F.: Tracing the influence of Mediterranean climate on Southeastern Europe during the past 350000 years, Sci. Rep., 6, 36334, doi:10.1038/srep36334, 2016.

Obreht, I., Hambach, U., Veres, D., Zeeden, C., Bösken, J., Stevens, T., Marković, S. B., Klasen, N., Brill, D., Burow, C., and Lehmkuhl, F.: Shift of large-scale atmospheric systems over Europe during late MIS 3 and implications for Modern Human dispersal, Sci. Rep., 7, 5848, doi:10.1038/s41598-017-06285-x, 2017.
Schmidt, C., Bösken, J., and Kolb, T.: Is there a common alphaefficiency in polymineral samples measured by various infrared stimulated luminescence protocols?, Geochronometria, 45, 160 172, doi:10.1515/geochr-2015-0095, 2018.

Willmes, C.: LGM sealevel change (HiRes), CRC806 database, available at: http://crc806db.uni-koeln.de/dataset/show/ lgm-sealevel-change-hires1436532921 (last access: 9 March 2016), 2015. 